\title{
Hegel and Lukács on the Novel
}

\section{Allen Speight}

\section{Introduction}

That Hegel was a significant influence on the young Georg Lukács' Theory of the Novel is a point few would dispute. ${ }^{1}$ Lukács himself insisted that the first part of $T N$ represented his own transition from Kantian to Hegelian theory, and most critics have subsequently affirmed the importance of Hegel to Lukács' pre- (or, depending on one's view, proto-) Marxist argument in TN. Yet the two are in some ways strange to take together in the context of novelistic theory. Despite the profusion of novelistic literature in his own time and his own significant appropriation of it for the limning of essential moments of the development of the world-historical spirit, Hegel's official Aesthetics hardly presents what one could claim to be an especially worked-out theory of the novel. The Aesthetics takes up literature in general primarily under the rubric of providing a theory of the genres of poetry - epic, lyric and dramatic - and what relatively few words Hegel actually devotes to the novel and prose literature in the lectures are tucked in corners: at the end of the discussion of the development of the epic, in the discussion of the historical form of the romantic, and in scattered comments elsewhere. ${ }^{2}$ As for $T N$, despite the strong connections some have drawn between Hegel and Lukács - Peter Demetz said that Lukács was 'in a certain sense ... the last Hegelian in the grand style' (Demetz 1967: 215) — others have questioned whether Lukács' work should be regarded primarily as making a contribution to the philosophy of literature in the tradition from which Hegel writes. ${ }^{3}$ And although much critical praise has been heaped on TN's discussion of the novel Harry Levin called it 'possibly the most penetrating essay that has ever addressed itself to the elusive subject of the novel' (Levin 1965: 150) — it is worth noticing that there are a number of topics familiar to other theoretical discussions of the novel that do not seem to play a central role in TN. Also, Lukács himself seems to express a desire to look beyond the genre altogether, in his claim that with Dostoevsky literature has moved on to other formal possibilities (TN 152-53).

To what extent, then, should we regard Lukács as offering in his early work a Hegelian theory of the novel? On Lukács' own self-critical analysis for the TN preface published more than 40 years after the first edition, he was, at the time of first writing, 'in the process of turning from Kant to Hegel' (TN 12), and the resulting method used in the work was a "fusion of "left" ethics and "right" epistemology' (TN 12). The two methods are on display in the two main parts of $T N$ : ' $[\mathrm{t}]$ he first, general part of the book is essentially determined by Hegel, e.g., the comparison of modes of totality in epic and dramatic art, the historico-philosophical view of what the epic and the novel have in common and of what differentiates them, etc.' (TN 15). The second part, the typology of novel forms, is presumably from the methodological assumptions of neo-Kantianism (in 


\section{Hegel and Lukács on the Novel}

Part II of TN, Lukács criticises the geisteswisschenschaftliche Methoden of this approach). The two halves certainly do diverge methodologically, but it is not clear that even the first half should be described in exclusively Hegelian terms, since Lukács himself, in the later preface, insists that Goethe, Schiller, Friedrich Schlegel and Solger were all important influences on him in ways that 'fill out and concretize the general Hegelian outline' (TN 15).

In what follows, I will compare and examine Hegel and Lukács' views of the novel as they are embedded within their theoretical views of genre, looking successively at their accounts of epic, drama and Romantic literature. I will conclude with an examination of two issues that raise specific questions for both theories: their theoretical openness to change, and the nature of the narrative philosophical genre in which both Hegel and Lukács self-reflectively worked.

\section{Hegel and Lukács on Epic}

Both Hegel and Lukács write from the perspective of a larger theory of literary genres, although these theories have clear differences. As mentioned, the primary interest of Hegel's genre theory seems to be to give a philosophical basis to a theory of poetic genres. This task offers a particular context for his well-known remarks about the prosaic forms of the modern, bourgeois world [die Prosa der Welt] and for the novel as the 'modern, bourgeois epic' [die moderne bürgerliche Epopoè] (LFA II.1092). Lukács, as well, seems to write $T N$ from the perspective of a working genre theory — although, as we will see, the dimensions of his theory raise interesting claims for his project.

Perhaps the best place to begin in comparing the genre theories of the two is with their treatment of epic, since Hegel and Lukács draw both strong points of connection and contrast between novelistic and epic forms. Several of Lukács' important claims about the nature of the epic form - its presentation of a world that exists as a totality that is rounded or closed from within; the good infinity that is present within it (as opposed to the bad infinity of the modern novelistic form); epic's concern with what is (empirically) present in that world rather than with what ought to or should be; its childlike character (as opposed to novelistic 'maturity'); its presence as a kind of home (again, in comparison with the 'transcendental homelessness' that Lukács takes to be distinctive of the novel); the objectivity of its general form - all have important resonances in Hegel's account of epic. At the same time, despite these significant points of connection between the two accounts, there are a number of important differences in the approaches that Hegel and Lukács take to epic which have not been frequently noticed within the critical literature.

(1) Epic Totality. Let us start with Lukács' claim that the epic 'gives form to a totality of life that is rounded from within' [eine von sich aus geschlossene Lebenstotalität] (TN 60). It is striking that some of Lukács' most theoretically-minded readers have failed to notice the Hegelian resonances in Lukács' appeal to 'totality' — de Man, for example, claimed that totality introduced '[a] definitely post-Hegelian element' into Lukács' 


\section{Allen Speight}

discussion (de Man 1971: 54). But Lukács could hardly have failed to notice the importance of totality in Hegel's discussion of poetry in general and of the epic in particular. For Hegel, it is 'as a totality of art, not exclusively confined by any onesidedness in its material to one particular sort of execution' that 'poetry takes for its specific form the different modes of artistic production in general'; and epic especially is the form in which 'poetry presents the developed totality of the spiritual world to our imagination' (LFA II.1037).

Similarly, Lukács' notion of a 'rounded' world that is 'closed within itself has clear roots in Hegel's treatment of epic poetry. Hegel likewise speaks of the 'unity and rounded whole of an epic work' [Einheit und Abrundung] and claims that epics present 'a rounded entirety of action' [ein abgerundetes Ganzes von Handlung] (LFA II.1087-88). In his account of epic totality, Lukács also repeatedly employs the distinctively Hegelian contrast between the 'good infinity' of the epic world and the 'bad infinity' of the novel (TN 81). And while Hegel does not use this contrast with anything like the systematic relentlessness that Lukács does, it is nonetheless detectable in his own treatment of epic, where the relating of a mere 'succession' of events is termed 'simply prosaic' and epic is said to have 'another kind of unity' (LFA II.1088).

(2) Epic Home, Epic 'Childlikeness'. Lukács' memorable description of the epic universe in the opening passages of the first chapter of $T N$ - 'The world is wide and yet it is like a home, for the fire that burns in the soul is of the same essential nature as the stars' (TN 29) - may rhetorically exceed anything that Hegel writes about the epic. But the notion of an epic rootedness is clearly present in Hegel's account, too:

Homer ... has spoken as one at home in his world, and where others are at home, we are too, for there we contemplate truth, the spirit living and possessing itself in its world, and we are well and cheerfully disposed because the poet is there too with his whole mind and spirit. (LFA II.1048)

Lukács' claim that the epic is the art-form of 'normative childlikeness' — in contrast with the 'virile maturity' associated with the novel — also finds a point of departure (even if less stressed) in Hegel's notion that 'in epic proper, the childlike consciousness of a people is expressed for the first time in poetic form' (LFA II.1045).

(3) Epic Objectivity. In the famous binary terms of $T N$, Lukács opposes the 'empirical, historically given' life expressed in the epic to the novel's concern with formgiving. A similar stress on the empirical life visible in epic can be found in Hegel. According to the Aesthetics, epic's topic is 'what is' (LFA II.1044), a point that Hegel draws etymologically from the root of epic in epos, or 'word', as well as from the Scandinavian 'saga': what these names for a poetic form 'state in general is what that thing is which has been transformed into "word" (LFA II.1040). What epic captures, in Hegel's view, is a sense of the persisting reality of individual things in the world - and 


\section{Hegel and Lukács on the Novel}

this in contrast with the status of objects in our experience of the modern world. As Hegel puts it in a frequently-quoted passage, Homer

does not dwell much on scenes in nature as our modern novels are fond of doing, whereas he is most circumstantial in his description of a staff, sceptre, bed, weapons, robes, door-posts, and he even does not forget to mention the hinges on which a door swings. In our case such things would seem very external and indifferent; indeed in our civilization our attitude to a mass of objects, things, and words is one of an extremely inflexible gentility and we have an extensive hierarchy of grades of distinction in clothing, furnishings, etc. Moreover, nowadays the production and preparation of any and every means of satisfying our needs is split up between such a multitude of activities in factories and workshops that all the particular steps in this wide ramification are reduced to something subordinate which we need not notice or enumerate. But the world of the heroes was not like this; there was a more primitive simplicity of objects and contrivances, and it was possible to linger over their description because all these things rank alike and are counted as something in which a man may take pride. (LFA II.1054)

According to Hegel, epic 'presents what is itself objective in its objectivity':

To describe ... events in their wholeness is the task of epic poetry which reports poetically in the form of the broad flow of events an action complete in itself and the characters who produced it, either as one of substantive worth or as adventurously intermixed with external accidents. (LFA II.1037)

For both Lukács and Hegel, the objectivity of epic requires the submission of subjectivity in two ways - both in the portrayal of epic heroes, whose inner character is embedded in a necessary chain of events, and in the role of the epic bard himself, who does not intrude into the epic narration of events but lets the work itself 'be its own minstrel'. ${ }^{4}$

Epic Differences. Yet, despite all the similarities and resonances between the two accounts of epic, there are important differences that must be taken into account, which perhaps suggest different approaches in the overall views of epic and genre theory that Hegel and Lukács are taking. In contrast with Lukács, Hegel offers a somewhat more complicated account of the collisions involved in epic, of bardic and heroic individuality, and of the possibility of modern epic.

(1) Epic Collision. Although one would scarcely know it from Lukács' citation of Hegel, a central element of Hegel's account of epic is in fact the notion of epic collision a kind of conflict which presages but is distinguished from his more well-known account of opposition in the tragic drama. Far from being the epic world which Lukács describes 


\section{Allen Speight}

as a place where 'the soul rests within itself even while it acts' (TN 29), Hegel's epic requires by its form a certain kind of elemental collision: 'The specific situation in which the epic state of the world is revealed to us must ... be of a kind productive of collision' (LFA II.1059). Epic, as opposed to tragic, collision (discussed below) is, in Hegel's view, especially characterised by a war in which the combatants fight external enemies (and not ones who either threaten civil war or some kind of intra-society division), and in which what matters is the natural side of character in bravery, rather than the spiritual motivations of tragic figures (such as the pathos of Antigone's tie to her family). Epic collision may have a second rank in Hegel's overall view of conflict-in-literature - he frequently points out the epic nature of a collision where a character is up against a nemesis of some sort, a situation that he finds terrifically un-tragic - but the importance of collision in an epic context remains essential to his account of the literary genre.

To be fair, Lukács does not deny the existence of epic conflict, but calls it 'safe'. He distinguishes it from the inherently risky quest-guided action captured in the novel: for the hero of epic, 'a long road lies before him, but within him there is no abyss'. Because of the 'adequacy of the deeds to the soul's inner demand for greatness' in epic, its heroes cannot be said to go out on real quests but, rather,

the soul goes out to seek adventures, it lives through adventures, but it does not know the real torment of seeking and the real danger of finding; such a soul never stakes itself; it does not yet know that it can lose itself, it never thinks of having to look for itself. Such an age is the age of the epic. (TN 33, 30)

Yet it is interesting to compare on this Hegel's very unLukácsian description of the epic world as having a kind of beauty that he describes not in terms of some kind of aesthetic bedrock solidity but, rather, in the somewhat more evanescent terms of a harmony that can only come about as the result of forces between which it lies. Consider Hegel's striking description of the various ways in which he thinks of epic as the result of such forces:

We find in the Homeric poems for the first time a world hovering beautifully between the foundations of life in the ethical order of family, state and religious belief, and the individual personal character; between spirit and nature in their beautiful equipoise; between intended action and external outcome; between the national ground of undertakings and the intentions and deeds of individuals. (LFA II.1098-99, my emphasis)

(2) Bardic and Heroic Individuality. As we have seen, both Lukács and Hegel view epic individuality, whether that of the hero or the bard, in terms of the objectivity of epic necessity. Epic characters are constrained by the necessity in the world around them, to which they must submit, and the bard as narrator has a voice which does not intrude 
upon the progress of the epic poem itself (LFA II.1069). But Hegel has a longer and somewhat more complicated story about the individuality of epic heroes than Lukács. For Hegel, there is in epic both a lyrical element of the expression of inner feelings and a dramatic exposition of justified and unjustified action which do play a role, even if they are 'asserted only as occasional features' (LFA II.1079). And while Hegel acknowledges, with Lukács, that the epic poet is somehow 'in' the objective poetry that he creates in a way that does not remove him self-consciously from the story, there is nonetheless a distinct individuality which can be attributed to the epic bard. Arguing against contemporary scholars (including his former seminary friend Schelling), who had suggested that the Homeric poems might have had a collective authorship, Hegel insisted that 'an epic poem as an actual work of art can spring from one individual only' ( $L F A$ II.1049). Part of Hegel's argument for that point is the personal developmental process that he thinks lay behind the act of epic composition. According to Hegel, the epic poet, in order to be a poet, must first define himself against an earlier, less-cultivated period, and in so doing must produce in himself a kind of self-awareness that is distinct, even while the bard remains somehow 'at home' in the world around him. 'Only when the poet, with freedom of spirit, flings off such a yoke [of an earlier uncultivated period], scrutinizes his own powers, has a worthy estimate of his own spirit, and therefore has got rid of a beclouded consciousness, can the period of epic proper dawn' (LFA II.1048).

(3) The Possibility of Modern Epic. As already mentioned, there is much in Hegel's view that gives rise to that of Lukács, including the definition of the Roman as the 'modern bourgeois epic'. And the official account that Hegel gives of the historical development of the epic form clearly traces a sequence that is consistent with Lukács' overall distinction between ancient and modern forms. This goes from what Hegel calls 'oriental' or symbolic epic, to classical (Greek and Roman) epic, to romantic epic poetry in the Christian world, with the novel or Roman 'finally ... tak[ing] the place of epic proper' (LFA II.1094). But while the outlines of this historical development are similar, Hegel seems to have more conceptual and historical space for the existence of a successful modern epic than Lukács does. On Hegel's view, the possibility for epic collision depends on a set of social and political factors which have indeed disappeared in the Europe of his day, where settled countries share borders with one another, but the consideration of epic's future potential leads to one of Hegel's rare moments of prognostication about other world-possibilities for future epics. The epics of the past have described

the triumph of the West over the East, of European moderation, and the individual beauty of a reason that sets limits to itself, over Asiatic brilliance ... If now in contrast to these epics we contemplate others that may perhaps be composed in the future, then these might have nothing to describe except the victory, some day or other, of living American rationality over imprisonment in particulars and measurements prolonged to infinity. (LFA II.1052) 


\section{Allen Speight}

\section{Hegel and Lukács on Drama}

Differences in Drama Theory. If we turn now to the treatments of drama in Hegel's Aesthetics and in Lukács' Theory of the Novel, there is in some ways an intensification of the differences we have already seen in comparing their views of epic.

If for Lukács the central question which epic answers is 'how can life become essential?', the central question of tragedy is 'how can essence become alive?' (TN 35) Tragedy is concerned, in other words, with a should rather than an is. And a should, as Lukács puts it, 'kills life' — a point that he draws more widely into a critique of conceptual attempts to construe life at all, including those of aesthetics and philosophical genre theory more specifically: "The "should-be" kills life, and every concept expresses a "should-be" of its object; that is why thought can never arrive at a real definition of life and why, perhaps, the philosophy of art is so much more adequate to tragedy than it is to the epic' (TN 48). On Lukács' view, it is the conceptual work of philosophy which ultimately 'revealed tragic destiny as the cruel and senseless arbitrariness of the empirical, the hero's passion as earth-bound and his self-accomplishment merely as the limitation of the contingent subject' (TN 35-36).

By contrast, Hegel's notion of tragic action must be distinguished from many traditional interpretations of ancient Greek tragedy — readings which Hegel thinks fail to do justice to the tragic texts themselves: the notion of fate as something utterly alien to a dramatic character or the notion that it is tragic when an agent's bubris is brought low. Both of these supposedly tragic plots, Hegel argues, actually fit better the events of epic where individual characters typically fit into a large pattern of circumstances beyond their control - than the actions of tragedy, which Hegel thinks (in a somewhat distinctive view of drama) are more reflective of 'who' tragic agents more intimately are. In fact, Hegel goes so far as to say that

what rules in epic, though not, as is commonly supposed, in drama, is fate. In drama, owing to the sort of aim which a character is determined to carry out in given and known circumstances, with all the resulting collisions, he creates his fate bimself, whereas an epic character has his fate made for him, and this power of circumstances, which gives his deed the imprint of an individual form, allocates his lot to him, and determines the outcome of his actions, is the proper dominion of fate. (LFA II.1070)

The difference between Lukács' perhaps more conventional view of tragic fate and Hegel's valorisation of tragic action as something nonetheless done and not only suffered by tragic agents points to a more significant difference regarding the Greeks and their conception of action and freedom. For Hegel, there is - despite the different and restrictive social formation of ancient Greek city life (the subordinated role of women 
and the lack of an explicit account of free human subjectivity as such) - a sense in which the Greeks experienced a 'genuine' kind of freedom. At least, such is the claim of some who read Hegel's account of the Greeks as giving a first (although more collective) gesture toward the ways in which agents can be said genuinely to identify with their actions. $^{5}$

Differences in the Consideration of the Novel and Other 'Romantic' Literature. As mentioned above, Hegel opens the door for Lukács' binary distinction of ancient epic from modern novel by suggesting that 'the novel [der Roman] takes the place of epic proper [den eigentlichen Epos]' (LFA II.1092). And Hegel likewise appears to set up for Lukács the notion of a prosaic modern successor form to the epic in which 'what is missing is the primitive poetic general situation out of which the epic proper proceeds'. What the modern novel presupposes instead, Hegel thinks, is 'a world already prosaically ordered' (LFA II.1092).

Both Hegel and Lukács also seem to be drawn to analyse what is distinctive about the forms of individuality that are expressed in works that lie at developmentally important places on the spectrum between ancient and modern literature. Both, for example, offer an unusually insightful reading of Dante's Divine Comedy as medieval epic and are drawn likewise to early forms of the modern novel in Cervantes and Goethe's Wilhelm Meister. Yet, as we have suggested, in comparison with Lukács, Hegel does not offer much in the way of a philosophical account either of the emergence of the novel in general or of specific novels whose interpretation might be important for understanding the romantic (or post-romantic) age. In fact, while Hegel acknowledges the wealth of material that might be considered in a treatment of the contemporary romantic novel, there is almost an abbreviated sense to the third section of Hegel's discussion of the historical forms of epic, the 'romantic epic', which Hegel concludes with the following wave of the hand:

In the other spheres of our present national and social life there is opened up in the domain of epic an unlimited field for romances, tales, and novels; yet I am unable here to pursue any further, even in the most general outline, the vast history of their development from their origin up to the present day. ( $L F A$ II.1110)

\section{Conclusions}

What kind of provisional conclusions can be drawn from this comparison of Lukács and Hegel with respect to their views of literary genre? What can we say in response to the initial question about whether Lukács' Theory of the Novel presents us with a Hegelian theory of the novel?

Let us begin with the most general issue facing their genre theories. In comparing the relative status of ancient and modern forms of literary art, both Lukács and Hegel 


\section{Allen Speight}

draw on a substantive and wider German aesthetic tradition - of which Schiller and Friedrich Schlegel are both representative - that marks an essential difference between the ancient (naïve, epic) and the modern (sentimental, Romantic). For Lukács, the crucial differences of methodology and inflection between his theoretical approach to the Greek/modern difference and that of Hegel are, in his words, "primarily social rather than aesthetic or philosophical in nature' (TN 18). Lukács mentions immediately in this context the historical context of TN's writing during the middle of the First World War, and his own sense that it was not Hegel but either Fichte — who provided Lukács with the memorable claim that the age of the novel was the 'age of absolute sinfulness' — or Kierkegaard who could be taken to be more in tune with the very different social and political world of 1914-1920.

Lukács' famous characterisation of the aesthetic differences between his approach and that of Hegel turns on the relation between the novel and the historical world condition in which it arose. If for Hegel the 'world of prose' is 'one in which the spirit has attained itself both in thought and in social and state praxis', then for a Hegelian 'art becomes problematic precisely because reality has become non-problematic' (TN 17). Lukács' own view of his approach is that it is 'the complete opposite of this: the problems of the novel form are here the mirror-image of a world gone out of joint. This is why the "prose" of life is here only a symptom, among many others, of the fact that reality no longer constitutes a favorable soil for art' (TN 17).

Lukács' rendering of the difference between his approach and Hegel's allows one to see how different the animating questions of each genre theory must be. For Lukács, one of the central questions of $T N$ becomes 'why is there modern tragedy and not modern epic?' This question seems to have a good deal less theoretical importance for Hegel's genre theory, in which, at least formally, there is a discussion of modern forms of each of the main poetic genres.

But it would be unfair to leave the differences between the two genre theories at Lukács' own self-analysis about his differences with Hegel regarding the viability of the bourgeois world in the age of prose and with the sweeping sorts of judgments about the 'incongruence of soul and deed' in the modern world that Hegel's philosophical and aesthetic stance reject. One important point that seems motivated by our comparison of Hegel and Lukács is not their differences with respect to the social adequacy of modern bourgeois institutions but, rather, their differences with respect to what was available within the Greek context. As suggested above in the discussion of their differing views of drama, Hegel, despite sharing a largely Schillerian frame of reference with Lukács, seems nonetheless to have assessed the achievements of the Greeks in a different way, to have seen more in the possibility of the ancient conception of freedom than Lukács did. And that difference may in turn make Lukács in the end more of a Romantic in his reading of the sharpness of the difference between ancient Greece and the modern world.

Hegel and Lukács on the Openness of Genres to Change and Development. Both Hegel and Lukács appear to have given serious thought to the question of literary genres' openness 


\section{Hegel and Lukács on the Novel}

to change and development. TN develops an important distinction, for example, between the change in what Lukács calls the Gesinnung relevant for a particular genre - the case he examines is the shift in the status of the hero and fate that emerges in the development of Euripidean drama - and the more fundamental change of the sort that the development of the novel represents, which Lukács terms a change in the principium stilisationis (TN 40). It is clear that the latter sort of change is precisely what artists of the rank of Dante, Cervantes and Goethe can achieve if they have the appropriate 'worldreceptivity' to large shifts such as that between the social world of ancient Greece and modern Europe.

It is a good question, however, what sort of changes, in TN's conception of the novel as genre, would need to be incorporated for a Lukácsian theory of the novel to be viable in contemporary terms. One example is that Lukács not only casts the modern novel in unusually gendered terms - next to epic 'childlikeness', the modern novel, remember, is characterised for Lukács by its gereifte Männlichkeit, or 'virile maturity' — but also leaves out of his story of the rise of the modern novel the important role that women played as authors, readers and subject matter in the development of the early novel. Since most contemporary theories of the novel's emergence give some account of the role of gender in the novel's development, it is worth asking both why Lukács ignores this side of the early modern novel and how his genre theory would appropriately incorporate it.

Hegel and Lukács on Philosophical Narrative. One final, and somewhat underdiscussed, question that is relevant to a comparison of Hegel and Lukács is that of the relation between the traditional literary genres and philosophy itself considered as a genre. The question is striking because - whatever larger views of genre the young Lukács may have had in this period - The Theory of the Novel suggests, perhaps somewhat surprisingly, that philosophy itself must be considered one of the essential literary genres. Although Lukács offers in TN some discussion of Hegel's three traditional genres epic, lyric and dramatic - his discussion of the development of Greek literature from Homer to Plato addresses interestingly the stages involved in the 'great and timeless paradigmatic forms of world literature' which are then listed as 'epic, tragedy and philosophy' (TN 35).

There is much that might be suggested about what Lukács has in mind in this claim. Lukács himself recalls in the preface that his original plan for $T N$ was imagined along the lines of a sort of philosophical dialogue among disaffected young people withdrawing from the world to discuss a range of available theoretical options. One perhaps might think here of a Lukácsian sort of Magic Mountain, or perhaps recall the Romantic context for the discussion of the novel in Schlegel's famous remark that novels were the 'Socratic dialogues of the age'.

What is striking for purposes of this comparison is that both Hegel and Lukács turned in a self-reflective way from questions of literary genre directly to the question of what sort of genre their philosophical works might represent, and both developed as a 


\title{
Allen Speight
}

consequence projects that can be characterised as a distinctive kind of philosophical narrative. J. M. Bernstein argues, in the conclusion to his study of $T N$, that the work has an essentially 'narrative context', one which 'figures (in the mode of a ghostly absence) the need for a collective narrative to replace and displace the narratives of interiority provided by the novel' (Bernstein 1984: 262). In the Phenomenology of Spirit, Hegel's placement of literary genre questions precedes the larger consideration of what sort of philosophical narrative the Phenomenology itself represents. ${ }^{6}$ And Hegel's larger project in absolute spirit already raises the question about how the treatment of artistic forms (with literary ones being the final such forms discussed) in the Aesthetics leads forward to the moments of religion and philosophy. ${ }^{7}$

Hegel and Lukács may differ in their theoretical treatments of the epic, drama and the novel, and both the elegiac tone of TN's account of the epic world and at least some of its hopeful animus for the future rests on a far more Romantic than Hegelian stance. Lukács' appeal to the 'new world' of literary formation, which he sees emerging in Tolstoy and especially Dostoevsky, is far more reminiscent of Schlegel's and Schelling's aesthetics than of anything in Hegel. But it is perhaps the commitment to philosophical narrative as a successor form to the work of literary genre theory that Hegel's Aesthetics and Lukács' Theory of the Novel have most in common.

\section{Allen Speight \\ Boston University \\ casp8@bu.edu}

\section{Notes}

\begin{abstract}
${ }^{1}$ Abbreviations:
TN: Lukács 1971.

LFA: Hegel 1975.

${ }^{2}$ Hegel did make considerable use of contemporary novels elsewhere - including, especially, his portrayal of the figure of the 'beautiful soul' in the Phenomenology of Spirit, although this appears to be a matter of his own literary or narrative practice and not something that led to an explicit theory of the novelistic form. See Speight 2001: 94-121.

${ }^{3}$ On the issue of how to place Lukács' approach to the novel in general, see Bernstein 1984.

${ }^{4}$ Hegel's account of the 'objectivity' of epic heroes stresses the larger pattern of events in which individuals are embedded (although, as will be seen below, this does not mean for Hegel that epic heroes are not individuals in a relevant sense); 'in epic, circumstances and external accidents count just as much as the character's will, and what he achieves passes before us just as what happens from without does, so that his deed must prove to be conditioned and brought about just as much by his entanglement in external circumstances. For in epic the individual does not act freely for himself and out of his own resources' (LFA II.1070). Hegel, in his account of the
\end{abstract}


role of the epic bard, also insists on the 'objectivity' of his situation: 'The poet as subject must retire in face of his object and lose himself in it ... the great epic style consists in the work's seeming to be its own minstrel and appearing independently without having any author to conduct it or be at its head' (LFA II.1048-49).

${ }^{5}$ See, for example, Pinkard 1994: 188.

${ }^{6}$ Hegel 1977: 239-53.

${ }^{7}$ For the relation between Hegel's nascent Jena theory of literary genres and the narrative philosophical project that constitutes the Phenomenology of Spirit, see Speight 2001: 37-41.

\section{Bibliography}

Bernstein, J. M. (1984), The Philosophy of the Novel: Lukács, Marxism and the Dialectics of Form. Minneapolis: University of Minnesota Press.

De Man, P. (1971), 'George Lukács' Theory of the Novel, in Blindness and Insight: Essays in the Rhetoric of Contemporary Criticism. Oxford: Oxford University Press.

Demetz, P. (1967), Marx, Engels, and the Poets. Chicago, IL: University of Chicago Press.

Hegel, G. W. F. (1970), Vorlesungen über die Ästhetik, Werke, vols xiii-xv, ed. E. Moldenhauer and K. M. Michel. Frankfurt: Suhrkamp.

Hegel, G. W. F. (1975), Hegel's Aesthetics: Lectures on Fine Art, trans. T. M. Knox, 2 vols. Oxford: Clarendon Press.

Hegel, G. W. F. (1977), Hegel's Phenomenology of Spirit, trans. A. V. Miller. Oxford: Oxford University Press.

Levin, H. (1965), 'Toward a Sociology of the Novel', Journal of the History of Ideas 26: 14854.

Lukács, G. (1963), Die Theore des Romans: ein geschichtsphilosophischer Versuch über die Formen der grossen Epik. Berlin: Hermann Luchterhand Verlag.

Lukács, G. (1971), Theory of the Novel: A Historico-Philosophical Essay on the Forms of Great Epic Literature, trans. Anna Bostock. Cambridge, MA: MIT Press.

Pinkard, T. (1994), Hegel's Phenomenology': The Sociality of Reason. Cambridge: Cambridge University Press.

Speight, A (2001), Hegel, Literature and the Problem of Agency. Cambridge: Cambridge University Press. 